\title{
FIRST RECORD OF THE BAND-TAILED PIGEON IN MANITOBA
}

WILLIAM J. WALLEY, 19 Edgar Avenue, Dauphin, Manitoba. R7N OR4

On 15 April $1982 \mathrm{Jim}$ Crozier of Dauphin, Manitoba identified a Bandtailed Pigeon in the yard at his farm (NW33-23-19-W1) located approximately $1.3 \mathrm{~km}$ northwest of the north entrance (Hwy. 10) to Riding Mountain National Park. The following day, identification was confirmed by $T$. Jenkins and later in the day by W. Clark and me. Several photographs of the bird were obtained at close range.

Field marks of the bird were observed at a distance of $40 \mathrm{~m}$ with a $20 \mathrm{x}$ spotting scope, then at 10-12 metres with $7 \times 35$ binoculars with the pigeon perched about $7 \mathrm{~m}$ up in a Bur Oak (Quercus macrocarpa). The bird was larger than our local Rock Dove. The under parts from the belly into the head were beige. The wings and back were grey. The bill was yellow with a black tip (the distal quarter). A narrow, but prominent white band occurred on the back of the neck with a green patch below this band which extended downward to the upper back. As the tail was held in a more-orless horizontal plane when the bird was perched, the grey band through it was seen only when short flights were made. Yellow feet and a red eye ring completed the colour characteristics of the visitor. Rock Doves were not observed in thie area.

Bent mentioned that in the states of Washington and California, Band-tailed Pigeons are associated with oaks in gulches where they feed on acorns, berries, etc. ${ }^{1}$ At Crozier's, the pigeon stayed at the crest of a deep ravine in a semi-open stand of Bur Oak and other hardwood deciduous trees. In the ensuing days, Crozier reported that the pigeon was feeding on acorns which had fallen to the ground, swallowing them whole. Although the bird had been in the yard only since the previous day, it had already established two favorite perches as observed by $\mathrm{Mr}$. Crozier. Both were less than $20 \mathrm{~m}$ from the house.

As I moved in to photograph it, the pigeon did not become fidgety until I was about $10 \mathrm{~m}$ away from the tree in which it was perched and when it flew, it was only a short distance to a nearby tree. Its tameness suggested that it may have been a caged bird that had escaped, but it was not banded. Alarm was displayed (extreme fidgeting) when a large hawk circled over the yard high up. Bent points out that Band-tailed Pigeons are preyed upon by Prairie Falcons and Cooper's Hawks. ${ }^{1} \mathrm{Mr}$. Crozier heard cooing sounds from the bird prior to our arrival. The pigeon was last seen at the Crozier farm yard on 27 April where it continued to feed on acorns, however, it apparently left shortly after that date.

According to Godfrey, the Bandtailed Pigeon's breeding range is from southern British Columbia, including Vancouver Island, Utah, and northcentral Colorado south to Baja, California and through the mountains of Mexico into Central America. ${ }^{4}$ He notes that it winters from southwestern United States (sometimes north to B.C.) southward. Robbins et al note its locally common status, especially in summer and its association with western oak and pine woods. ${ }^{8}$

Houston lists three hypothetical records (no material evidence) for Sask- 


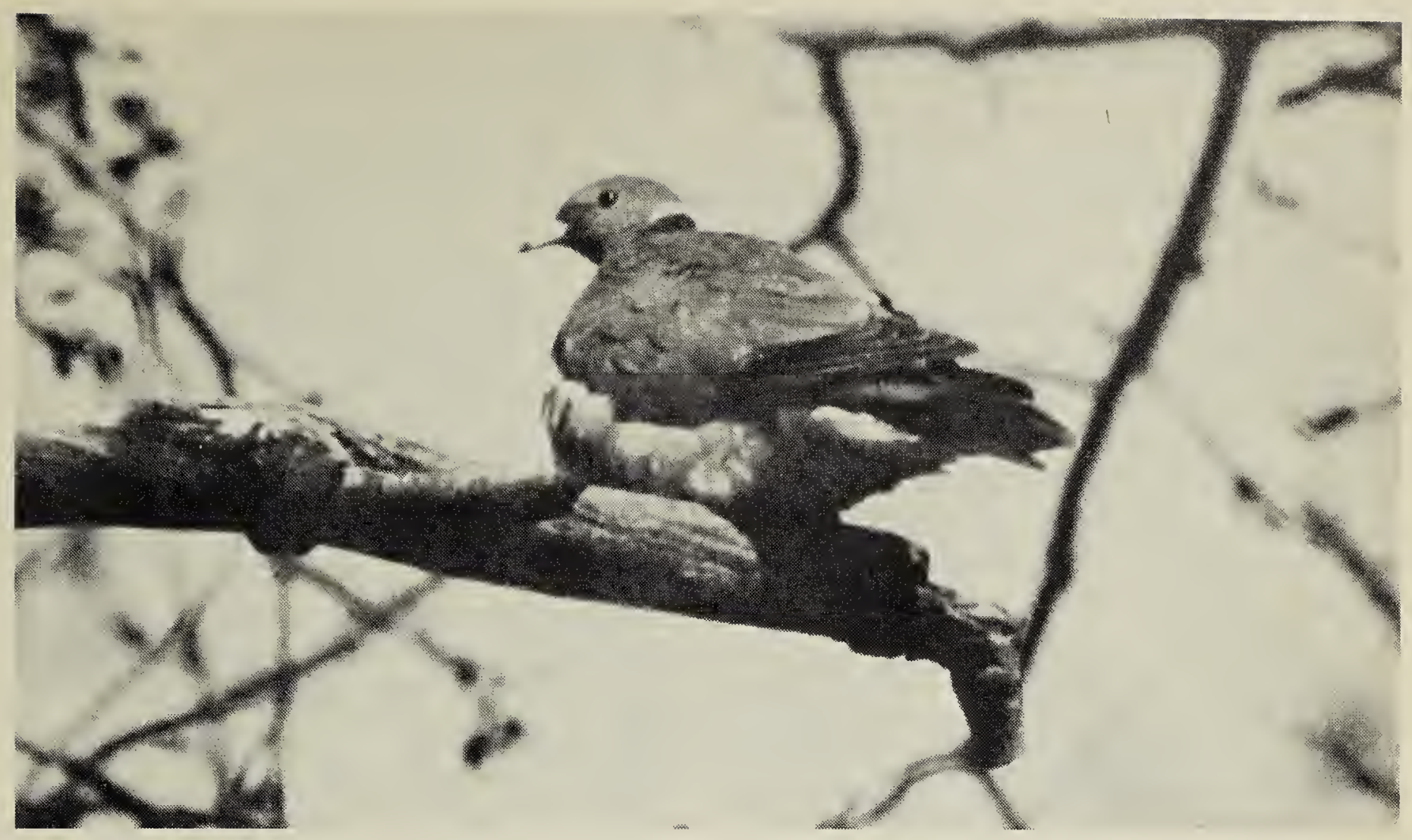

Band-tailed Pigeon.

W. J. Walley

atchewan and Weidl reports a fourth record for that province that Dr. Houston would also classify as hypothetical because of the failure to obtain material evidence. ${ }^{6} 9$ In Manitoba, no records are given in recent regional publications by Gardner, Cleveland et al or by Knapton. ${ }^{2} 7$ According to Hatch, this sighting is the first record for Manitoba. ${ }^{5} \mathrm{He}$ notes, however, that a second sighting was made in Manitoba in 1982 when one was identified at Churchill in June.

\section{Acknowledgements}

The author is grateful to Garth Ball of the Manitoba Department of Natural Resources for furnishing a copy of Bent's article on the Band-tailed Pigeon. Appreciation is also extended to David Hatch for verifying the record as the first in Manitoba and for informing me about the Churchill record.

1 BENT, A. C. 1932. Life histories of North American gallinaceous birds. Dover publications New York. (1963 reprint)

${ }^{2}$ CLEVELAND, N. J., C. W. CUTHBERT, G. D. GRIEEF, G. E. HOLLAND, P. A. HORCH, R. W. KNAPTON, R. F.
KOES, N. F. MURDOCH, W. P. NEILY and I. A. WARD. 1980. Birder's guide to southeastern Manitoba. Eco Series No. 1. Manitoba Naturalists Society, Winnipeg. 58 pp.

${ }^{3}$ GARDNER, K. A. 1981. Birds of Oak Hammock marsh wildlife management area. Wildlife Branch, Manitoba Dept. of Natural Resources. 172 pp.

${ }^{4}$ GODFREY, W. E. 1966. The birds of Canada. Natl. Mus. Can. No. 203. Biol. Series No. 73. Ottawa. 428 pp.

${ }^{5} \mathrm{HATCH}$, DAVID. March 11, 1983. Chickadee Notes. Winnipeg Free Press.

${ }^{6}$ HOUSTON, C. S., M. I. HOUSTON, and J. B. GOLLOP. 1981. Saskatchewan bird species - hypothetical and rejected. Blue Jay 39(4):196-201.

${ }^{7}$ KNAPTON, R.W. 1979. Birds of the Gainsborough - Lyleton Region (Saskatchewan and Manitoba). Special Publication No. 10. Saskatchewan Natural History Society. Regina $72 \mathrm{pp}$.

${ }^{8}$ ROBBINS, C. S., B. BRUUN, and H.S. ZIM. 1966. Birds of North America. Golden Press. New York. 340 pp.

${ }^{9}$ WEIDL, D. A. 1982. Band-tailed Pigeon near Herbert, Saskatchewan. Blue Jay 40(3): $169-170$. 